\title{
Urticaceae for the non-specialist: Identification in the Flora Malesiana region, Indochina and Thailand
}

\author{
C.M. Wilmot-Dear ${ }^{1}$
}

\section{Key words}

diagnostic characters

Flora Malesiana

genera

Indochina

keys

Thailand

tribes

Urticaceae
Abstract Urticaceae comprises five tribes. Most specimens can be identified to tribe, many to genus, by the nonspecialist. Keys are provided to the tribes and to the genera within each tribe, based on the more easily observable diagnostic characters. Additional notes to each genus are also given.

Published on 30 October 2009

\section{INTRODUCTION}

This paper aims to provide the non-specialist with aids to the identification of Urticaceae. Almost all the information is already available somewhere in the literature, but many existing keys to Urticaceae are unsatisfactory, because of the extent to which they use minute floral characters, which are either difficult for the non-specialist to observe and interpret or are absent in plants of the wrong sex or stage of development. An illustrated talk on the gross morphology of Urticaceae presented at the most recent Flora Malesiana conference elicited many requests for a brief non-specialist's guide to the family. The following keys and brief notes on diagnostic characters are produced in response to those requests. They are a distillation of what I have found most helpful over the years. Wherever possible those characters which are less easy to interpret or depend on the presence of flowers of one sex have been avoided or are included only as supplementary information. The information and keys given below are applicable to the particular genera found in the Flora Malesiana region, Indochina and Thailand; therefore keys will not always 'work' for taxa found elsewhere.

The five tribes which make up the family represent distinct groups easy to recognise by gross morphology. It is therefore usually possible to identify material at least to tribe on fairly easily observable characters. Tribes Elatostemeae and (usually) Urticeae are recognisable worldwide, even without flowers, on the characters given in the tribal key below. Within each of these two tribes five genera occur in the region and the larger genera are mostly distinguishable from one another without flowers. Tribes Parietarieae and Forsskaoleeae are each represented by only one species and identification to tribe requires flowers. The distinctive inflorescence characters within Parietaria are easy to observe with a hand-lens. However, inflorescences of Droguetia (tribe Forsskaoleeae) are hard to interpret due to its highly reduced flower parts; it is frequently confused with the fifth tribe, Boehmerieae, many of whose genera (13 occurring in the region) are hard to distinguish from one another. Difficulties are discussed (below) under the individual tribes and genera.

\footnotetext{
1 The Herbarium, Royal Botanic Gardens, Kew, Richmond, Surrey, TW9 3AE, United Kingdom.
}

\section{KEY TO TRIBES}

(The numbers in front of the tribal names refer to the keys to the genera)

1. Stinging hairs present (see note under keys), at least on inflorescence, or if apparently absent then always a tree with pistillate flowers and fruit laterally compressed and asymmetrical (Fig. 1d, e) with markedly eccentric linear stigma, individual flowers easily distinguished in lax racemes or panicles. Herbs, shrubs or trees .... 1. Urticeae (Fig. 1)

1. Stinging hairs absent. Fruit mostly \pm straight, but if markedly compressed and asymmetrical then with capitate stigma and in often tightly congested flower cluster. Herbs, shrubs or scramblers . . . . . . . . . . . . . . . . . . . 2

2. Inflorescences dichotomously branched with conspicuous, paired, broad bracts at each node including flowerless lower nodes, uppermost bract-pair completely enveloping flower clusters in bud. - Leaves alternate, entire; cystoliths mostly linear, stigma capitate or short-ligulate. Woody scramblers $\ldots \ldots \ldots \ldots \ldots \ldots \ldots \ldots$. Poikilospermum (Fig. 5m;

2. Inflorescences various but if dichotomous then bracts only present associated with a flower cluster and never so large as to completely envelop flower clusters (habit, leaves, cystoliths and stigma various) . . . . . . . . . . 3

3. Cystoliths elongate (Fig. 2b). Stigma capitate-penicillate (Fig. 2a). Staminate flowers 4- or 5-merous with conspicuous perianth lobes (Fig. 2c), very rarely with 6 perianth lobes and 3 stamens . . . . . . . . . . . . 2. Elatostemeae (Fig. 2)

3. Cystoliths dot-like. Stigma capitate, peltate, capitate-penicillate or linear. Staminate flowers 1-5-merous, perianth lobes conspicuous or not $\ldots \ldots \ldots \ldots \ldots \ldots \ldots$

4. Inflorescences axillary with 1-few flowers, both sexes (usually) present on each plant and both subtended by green leaf-like bracts longer than the flower. Pistillate flowers with conspicuous papery light brown tubular perianth which dehisces longitudinally to reveal a contrastingly-coloured shiny black achene; hermaphrodite flowers, larger than normal pistillate flowers, often also present; stigma penicillate-capitate. Small herbs with green leaves ......... . . . . . . . Parietarieae (Fig 6; only Parietaria in region) 
4. Inflorescence with few or many flowers but without this conspicuously contrasting-coloured combination of green, brown and shiny-black parts. Pistillate perianth tightly adnate to achene or breaking up at maturity, 'pistillate' flowers not dimorphic; flowers often in crowded sessile or pedunculate heads with individual parts difficult to distinguish. Herbs, shrubs or small trees often with discolorous leaves (Fig. $3-5,7)$.

5. Flowers grouped into a single to several, usually bisexual, clusters in each axil, each cluster surrounded by a row of partly-fused bracts forming a specialized involucre. Flowers highly reduced, staminate perianth a single boat-shaped lobe enclosing single stamen; pistillate perianth (apparently) absent, stigma filiform. Small herbs

....... Forsskaoleeae (Fig. 7; only Droguetia in region)

5. Flowers variously arranged in loose axillary clusters, or in clusters along spike-like or paniculate flowering axes, or inserted on a receptacle but cluster never surrounded by an involucre; staminate flowers with (2-)3-5 conspicuous \pm free lobes (Fig. 3e, 4c, 5h) and same number of stamens; pistillate perianth often conspicuous, stigma filiform or capitate-penicillate. Herbs, erect or climbing shrubs or trees. .

3. Boehmerieae (Fig. 3-5)

\section{KEYS TO GENERA}

\section{Tribe 1. Urticeae - Fig. 1}

1. Leaves opposite, margin toothed. Pistillate flower and fruit \pm straight (Fig. 1a) with terminal, capitate-penicillate stigma. Herbs . . . . . . . . . . . . . . . . . . . . Urtica

1. Leaves alternate, margin toothed or entire. Pistillate flower and fruit straight or curved, stigma capitate or linear, terminal or eccentric. Herbs to trees . . . . . . . . . . . 2

2. Small herbs $<0.5 \mathrm{~m}$. Stipules interpetiolar. Pistillate flower and fruit straight with terminal capitate stigma. Nanocnide

2. Shrubs, trees or herbs usually $>0.5 \mathrm{~m}$. Stipules intrapetiolar. Pistillate flower and fruit asymmetrical and often markedly laterally compressed (Fig. 1d, e), stigma filiform or ligulate, usually \pm eccentric . . . . . . . . . . . . 3

3. Trees or shrubs with leathery entire or only shallowly crenate leaves. Pistillate pedicels absent or terete, never winged. Fruits often somewhat fleshy. Stipules connate to their apex. Stinging hairs often sparse and inconspicuous .

........................ Dendrocnide toothed leaves. Pistillate pedicels often winged laterally or dorsiventrally. Fruits never fleshy. Stipules partly connate (i.e. apex of stipule pair bifid). Stinging hairs conspicuous

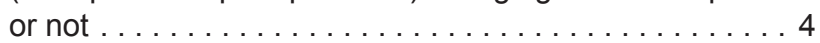

4. Stinging hairs large, robust, dense and conspicuous, at least some $>5 \mathrm{~mm}$ long. Leaves deeply dentate to 3-7-lobed. Pistillate perianth lobes 3 , connate (fourth lobe absent or reduced to a bristle). Robust herbs .. Girardinia (Fig. 1f, g)

4. Stinging hairs often slender and inconspicuous, always $<4$ $\mathrm{mm}$ long. Leaves shallowly dentate or serrate. Pistillate perianth lobes 4, unequal, free to base or almost so. Herbs, shrubs or trees. . . . . . . . . . . . Laportea (Fig. 1b-e)

\section{Tribe 2. Elatostemeae - Fig. 2}

1. Leaves opposite, two leaves of pair similar in size or larger leaf $\leq 3$ times size of smaller . . . . . . . . . . 2

1. Leaves alternate and often distichous and 'fern-like', (Fig. $2 \mathrm{~g}$ ), rarely opposite or subopposite but then with second leaf minute and very soon caducous (Fig. $2 \mathrm{~h}$ ) ........ 3
2. Inflorescences (both sexes) capitate, consisting of a pedunculate cup-shaped or discoid involucrate receptacle.

Lecanthus (Fig. 2d, e)

2. Flowers in spikes, loose cymes or panicles or if in crowded clusters then without a receptacle ....... Pilea (Fig. 2a-c)

3. Staminate flowers with 6 perianth-lobes and 3 stamens and always solitary, never in capitate inflorescences (Indochina)

$\ldots \ldots \ldots \ldots \ldots \ldots \ldots \ldots$. . . . . . . . . . . . . . . . . . .

3. Staminate flowers with 4 or 5 perianth lobes and same number of stamens, flowers often in capitate inflorescences (wide-

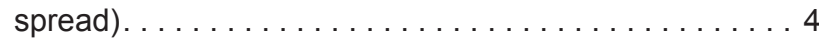

4. Pistillate inflorescences capitate subglobose fleshy receptacles without involucral bracts (Fig. 2j); staminate ones similar or cymose . . . . . . . . . . . . Procris (Fig. $2 \mathrm{~h}-\mathrm{j}$ )

4. Pistillate inflorescences loosely cymose or a capitate receptacle (Fig. 2f) surrounded by involucral bracts; staminate ones capitate-involucrate or cymose.

Elatostema (Fig. 2f, g)

Tribe 3. Boehmerieae - Fig. 3-5

(Note: identification to genus often requires pistillate inflorescences)

1. Leaves opposite ..................... . 2

1. Leaves alternate . . . . . . . . . . . . 5

2. Stigma capitate on short style. Small herbs Chamabainia

2. Stigma filiform (Fig. $4 a-c, f, g$ ). Herbs to trees . . . . . 3

3. Stigma hooked, minute, $<0.5 \mathrm{~mm}$ long (Fig. 4a), persistent. Fruit asymmetrically enlarged at apex (Fig. 4b). Inflorescences axillary, a pair at each node, pistillate inflorescences (often also staminate ones) consisting of densely crowded, sessile, \pm globose clusters partly enveloping stem. Trees or shrubs . . . . . . . . . . . Cypholophus (Fig. 4a, b)

3. Stigma curved or straight (Fig. 4c, f, g), rarely hooked but always $>1 \mathrm{~mm}$ long, often $2-4 \mathrm{~mm}$. Fruit usually constricted at apex, often also ribbed or compressed and winged (Fig. $4 d, e, h)$. Inflorescences either loose or densely crowded axillary clusters (Fig. 3e, 4c) or clusters arranged along long spike-like or branched often leafless flowering axes (Fig. $3 a-c)$. Herbs, shrubs or small trees . . . . . . . 4

4. Achene shiny, easily detached from perianth at maturity; stigma usually caducous from young fruit. Staminate and pistillate flower-clusters loose (Fig. 4c), flowers easily visible . . . . . . . . . . . . . . . . . Pouzolzia (Fig. 4c-e)

4. Achene not shiny, remaining attached to persistent perianth; stigma persistent. Flowers often so densely crowded in cluster that only apices visible . . Boehmeria (Fig. 3, 4f-h)

5. Pistillate inflorescences consisting of an unbranched peduncle terminated by several broad flattened lobed recurved 'sponge-like' receptacular masses with flowers only on upper side. Staminate inflorescences consisting of a branched peduncle, each branch apex flattened and narrowly-oblong with flowers arranged on one side....... Astrothalamus

5. Pistillate and staminate inflorescences in clusters variously arranged, either single or paired in leaf-axils (Fig. 3e, 5e) or along \pm linear branched or unbranched axes (Fig. 3a-c, $4 \mathrm{j}$ ), but if only at apex of axis-branches (Fig. 5a, b, i) then clearly globose, never forming a flattened mass . . . . . 6

6 . Flower-clusters contiguous along one side of \pm linear branched axes which are slightly flattened, clusters completely concealing axis throughout its length but only on that side. Pistillate perianth becoming fleshy; stigma ring-like (Indochina) . . . . . . . . . . . Sarcochlamys (Fig. 4j-l)

6. Flower-clusters either in leaf-axils (Fig. $3 e, 5 e$ ) or along \pm linear terete branched or unbranched axes (Fig. 3a-c, 5a), but if crowded then concealing axis on all sides (Fig. 3b). Stigma filiform, peltate or capitate-penicillate . . . . . 7 
7. Stigma short-ligulate. Pistillate perianth completely enveloping achene. Flower-clusters (both sexes) small, arranged along short laxly-branched partly-dichotomous axes, each cluster with few $(<10)$ flowers. Shrub (Indochina) . . . . . . . . . . . . . . . . . . . . . . . . Archiboehmeria

7. Plant without above combination of characters. Stigma usually either clearly filiform (Fig. 4c, $\mathrm{f}-\mathrm{i}$ ) or capitate to peltate or capitate-penicillate (Fig. $5 \mathrm{~d}, \mathrm{~g}, \mathrm{j}$ ), but if apparently ligulate and inflorescences dichotomous then clusters (both sexes) with many densely-crowded flowers (Fig. 5a, b). Pistillate perianth sometimes surrounding only lower part of achene (Fig. $5 \mathrm{~g}$ ). Flower clusters often sessile in leaf-axils or arranged along unbranched axes (Fig. 3). Herb, shrub or tree ..................... 8

8. Stigma filiform. Pistillate perianth completely enveloping achene (Fig. 4c, f-i). Flower-clusters either \pm sessile (never distinctly short-pedunculate) in leaf axils (Fig. 3d, e) or arranged along unbranched spike-like or branched axes (Fig. 3a-c). Herbs to trees . . . . . . . . . . . 9

8. Stigma capitate to peltate or capitate-penicillate, rarely \pm ligulate (Fig. $5 \mathrm{~d}, \mathrm{~g}, \mathrm{~h}, \mathrm{j}$ ). Pistillate perianth often surrounding only lower part of achene (Fig. $5 \mathrm{~g}$ ). Flower clusters either on \pm distinct short peduncle in leaf-axils (Fig. 5e) or arranged along branched axes (Fig. 5a) . . . . . . . . . . 13

9. Pistillate perianth succulent at maturity with clearly visible dark round opening at apex (Fig. 4i) after stigma caducous, not markedly laterally compressed and without wings or distinct ribs . . . . . . . . . . . . . . . . 10

9. Pistillate perianth not succulent at maturity, \pm constricted at apex (Fig. 4c) and without dark round opening, often with distinct longitudinal ribs (Fig. $4 \mathrm{e}$ ) or markedly laterally compressed and winged (Fig. 4d, h); stigma persistent (Fig. 4h) or not (Fig. 4d, e) . . . . . . . . . . . . . 11

10. Scrambling subshrub. Leaves entire....... Nothocnide

10. Erect shrub. Leaves toothed . . . . . . . Pipturus (Fig. 4i)

11. Slender herb with small bisexual flower-clusters arranged along slender leafless unbranched spike-like axes. Staminate flowers 2-merous. . . . . . . . . . . Neodistemon

11. Herb or shrub with flower-clusters variously axillary or along branched or unbranched axes (Fig. 3) but staminate flowers 3-5-merous (Fig. 4c) . . . . . . . . . . . . . 12

12. Achene shiny, easily detached from perianth at maturity; stigma usually caducous from young fruit. Staminate and pistillate flower-clusters loose, flowers easily visible. . . . ... . . . . . . . . . . . . . . . . . Pouzolzia (Fig. 4c-e)

12. Achene not shiny, remaining attached to persistent perianth; stigma persistent. Flowers often so densely crowded in cluster that only apices visible. Boehmeria (Fig. 3, 4f-h)

13. Inflorescences (both sexes) dense, \pm globose heads of flowers, arranged on a receptacle (Fig. $5 \mathrm{c}, \mathrm{f}$ ), heads pedunculate on simple (Fig. 5e) or dichotomously branched (Fig. 5a, b) axes. Stipules partly or entirely connate, intrapetiolar 14

13. Inflorescences small rather loose clusters on dichotomous axes without receptacle (Fig. $5 \mathrm{~h}$ ) or each pistillate flower with individual receptacle (Fig. $5 \mathrm{i}-\mathrm{k}$ ). Stipules free or connate . . . . . . . . . . . . . . . . . . . 15

14. Pistillate perianth lobed, surrounding only lower half of achene (Fig. $5 \mathrm{~g}$ ). Fruit markedly laterally compressed, stigma often slightly eccentric. Inflorescence-heads a pair in each axil (Fig. 5e), each on a short unbranched peduncle . . . . . . . . . . . . . . . . . Leucosyke (Fig. 5e-g)

14. Pistillate perianth tubular enveloping mature achene (Fig. $5 d$ ), often fleshy. Fruit only slightly laterally compressed, stigma terminal. Inflorescence axes often dichotomously branched once or several times Debregeasia (Fig. 5a-d)
15. Pistillate flowers and fruits each surrounded at base or almost completely enveloped by a conspicuous discoid or cup-like fleshy receptacle; perianth thin-textured enveloping and adnate to achene; fruit not markedly laterally compressed; stigma terminal, broadly peltate with fringe of long hairs. Stipules free ........ Oreocnide (Fig. $5 \mathrm{i}-\mathrm{k}$ )

15. Pistillate flowers without fleshy receptacle; perianth connate around lower half of achene or so inconspicuous as to appear absent; fruit often markedly laterally compressed or 3-angled; stigma often slightly eccentric, capitate-penicillate. Stipules partly connate ....... Maoutia (Fig. 5h)

\section{A note on stinging hairs}

Although stinging hairs are obvious in living material they may become inconspicuous on drying if they are sparse, small and mainly confined to the inflorescence. They are distinguished from other kinds of indumentum found in Urticaceae by the following combination of characters discernible with a handlens: They are unicellular, colourless-('glass-like')-translucent, straight (this is sometimes unclear in dried pressed material if fragile hairs become distorted). However, the best character (apparent even in pressed material) is that they are distinctly and evenly tapered to a markedly acute apex.

\section{Checklist of most easily-visible characters for tribes and genera}

- Stinging hairs. Urticeae (almost always present).

- Shrub or tree. Urticeae (Dendrocnide only); Boehmerieae (most genera except Chamabainia and Neodistemon).

- Woody scrambler. Poikilospermum; Nothocnide.

- Herb. Urticeae (except Dendrocnide); Boehmerieae (only Boehmeria, Chamabainia, Neodistemon, Pouzolzia); Droguetia; Parietaria.

- Leaves deeply 3-5-lobed. Girardinia; Boehmeria (few).

- Leaves discolorous. Boehmerieae (some); (other regions Forsskaoleeae).

- Leaves opposite. Urticeae (Urtica only); Elatostemeae (Pilea, Lecanthus); Boehmereae (only Boehmeria, Chamabainia (all), Cypholophus (all) and Pouzolzia).

- Leaves alternate. Urticeae (except Urtica); Elatostemeae (Elatostema, Petelotiella); Boehmerieae (most genera).

- Leaves distichous giving 'fern-like' appearance to stems, often combined with creeping habit. Elatostemeae (some).

- Cystoliths elongate. Elatostemeae (Fig. 2a), Urticeae (some); Poikilospermum (some). Cannot be Boehmerieae (worldwide), Parietaria or Droguetia.

- Flowers arranged on broad flattened-discoid, flattenedlobed or cup-shaped receptacular structures (sessile or pedunculate), sometimes surrounded by involucre of fused bracts (Fig. 2f). Elatostemeae (some); Boehmerieae (only Astrothalamus).

- Flowers surrounded by involucre of fused bracts but not arranged on a receptacle (Fig. 6). Forsskaoleeae (in this region).

- Inflorescences dense subglobose heads (sessile or pedunculate), completely enveloped in bud by pair of bracts (Fig. 5I). Poikilospermum.

- Inflorescences dense subglobose heads without enveloping bracts. Procris (Fig. 2h, i) or Boehmerieae (Fig. 3-5).

- Inflorescences dichotomous (flowers in clusters or lax cymes) with pairs of large bracts even at lower (flowerless) nodes (Fig. 5I). Poikilospermum.

- Stigma long and filiform. Cannot be Elatostemeae, Parietaria or Poikilospermum.

- Achenes large and conspicuous, laterally compressed and asymmetrical with markedly eccentric style and downcurved filiform stigma (Fig. 1d, e) the whole structure remi- 
niscent of Daphnia or Pulex. Urticeae (Dendrocnide and Laportea).

- Achenes laterally compressed but only slightly asymmetrical, style eccentric but stigma capitate (Fig. $5 \mathrm{~h}$ ). Boehmerieae (Leucosyke, Maoutia).

\section{NOTES ON THE GENERA}

\section{Poikilospermum Zipp. ex Moritzi — Fig. 5I}

This genus has been included variously within Cecropiaceae or Urticaceae and was revised with a detailed discussion of its systematic position by Chew (1963). It is a woody scrambler with entire often leathery, often strongly-veined leaves with cystoliths often elongate and inflorescences paired or several times dichotomous with the flowers (variously in tight globose clusters or more loosely arranged) towards the apex of branches; the stigma is capitate. Its large bracts at the lower (flowerless) dichotomies of the inflorescence and similarly large bracts completely enveloping the young inflorescence distinguish it from several genera in Urticaceae tribe Boehmerieae with dichotomous inflorescences. Dendrocnide, which often has very similar leaves, can be confused with this genus but differs in being a tree.

\section{Tribe 1. Urticeae - Fig. 1}

This tribe is usually easily recognised in the living state by stinging hairs (see note above), which are unique to this tribe and present in most or all species of most genera. Leaves are never discolorous; achenes in several genera (including those where stinging hairs are inconspicuous or apparently absent) are also diagnostic, distinctively 'Daphnia-like' (see spot-characters above) laterally compressed-asymmetric and often warty with a distinctly eccentric filiform stigma. Dried material with sparse or inconspicuous stinging hairs and without pistillate flowers may be mistaken for two other tribes, Elatostemeae (cystoliths are often elongate as in all Elatostemeae; leaf morphology of Dendrocnide and Laportea is sometimes similar to Elatostema) or Boehmerieae (leaf morphology of Laportea and Urtica often similar to Boehmeria).

Dendrocnide Miq. (> 36 species). Revised by Chew (1969a). Easily distinguished from others in the tribe in being a tree or (rarely) \pm shrubby; leaves are never deeply toothed, at most crenate and often leathery with robust veins ; achenes are compressed-asymmetric with eccentric style, very like those of Laportea. Stinging hairs are often inconspicuous or occasionally completely absent, and it can be confused with Poikilospermum (q.v.).
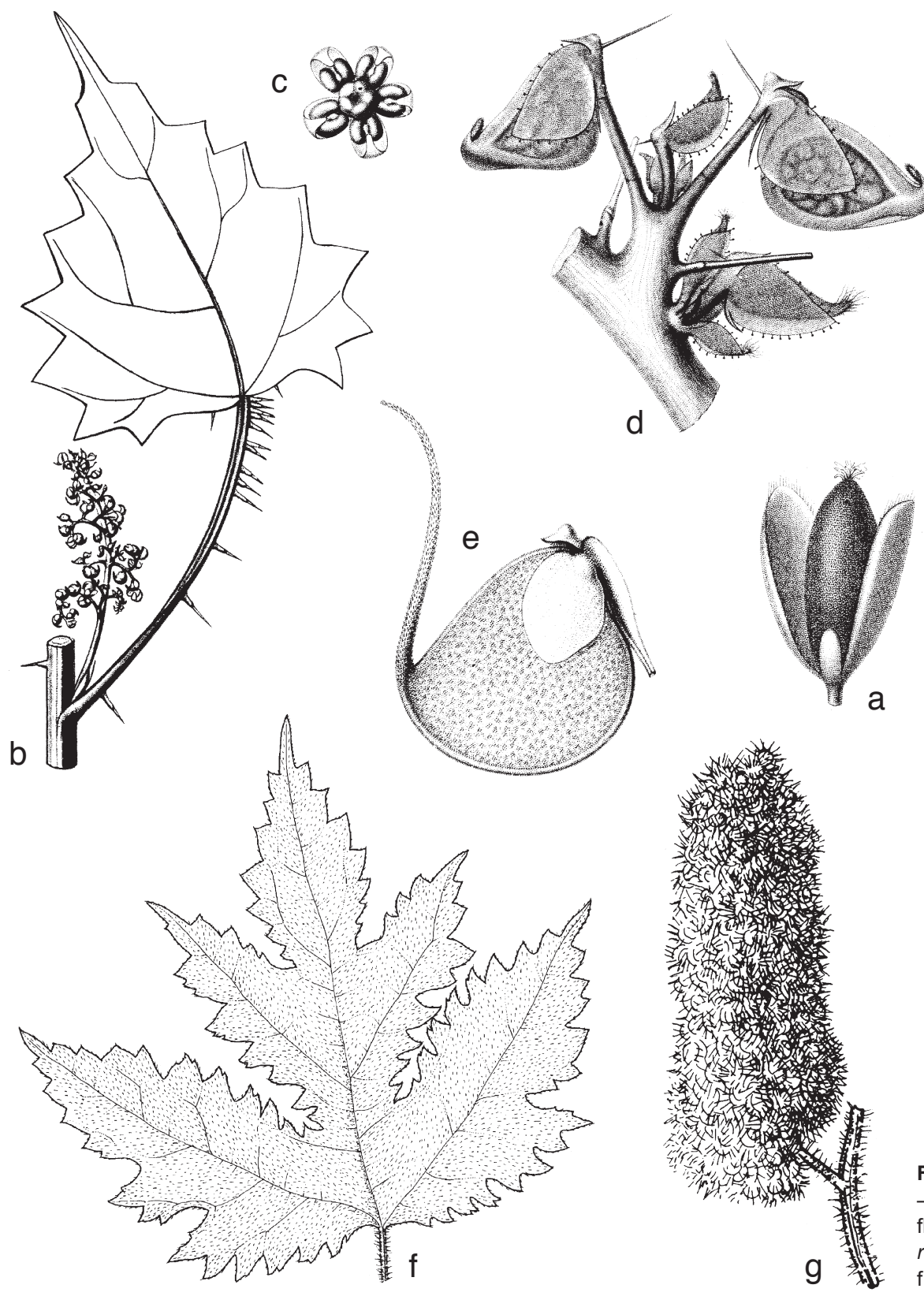

Fig. 1 Tribe Urticeae. - a. Urtica: Pistillate flower. - b-e. Laportea: b. portion of fruiting stem; c. staminate flower; d. cluster of fruits; e. pistillate flower. - f, g. Girardinia: f. Leaf; g. inflorescence (a-e: Weddell (1856); f, g: Friis (1989a), drawn by V. Friis). 
Girardinia Gaudich. Fig. 1f, g. (One highly variable species is present in the region, G. diversifolia (Link) Friis). Revised by Friis (1981). It is an erect annual or short-lived perennial herb easily recognised by its extremely long robust stinging hairs and usually a deeply incised leaf margin, leaves being double-dentate or 3-5-lobed; achenes are compressedasymmetric. Pistillate inflorescences are dense panicles with the branches, flowers and fruit often almost completely obscured by the dense mass of long stinging hairs.

Laportea Gaudich. Fig. 1b-e (c. 7 species in the region). It was revised by Chew $(1965,1969 b)$. It is a herb or sometimes shrub often very similar in leaf form to Urtica and Nanocnide, but distinguished from Urtica on alternate leaves and from both on its compressed-asymmetric achenes with a filiform eccentric stigma.

Nanocnide Blume (1 species in Indochina, N. japonica Blume). It is a small herb distinguished from Urtica only by alternate leaves.

Urtica L. Fig. 1a (c. 3 species in the region). Some infrageneric entities are morphologically very plastic and regional treatments are unharmonised. Annual or perennial herbs, rarely subshrubs, easily distinguished from other genera in the tribe by the opposite leaves. Leaves are never entire; the achene is straight with a terminal style and capitate-penicillate stigma.

\section{Tribe 2. Elatostemeae - Fig. 2}

Herbs or small shrubs that are a very common component of the forest understory. Many species are prostrate in habit and some are epiphytes. The tribe can be recognised on a combination of two vegetative characters, linear cystoliths (only clearly visible in dried material) and the absence of stinging hairs (this combination is otherwise seen only in Poikilospermum (above), which differs markedly in the presence of conspicuous paired bracts in lower, non flowering, parts of the inflorescence). Inflorescence-architecture is widely varying but the stigma is always capitate.

Elatostema J.R.Forst. \& G.Forst. (incl. Pellionia). Fig. 2f, g. (> 200 species in the region). Distinguished from Pilea and Lecanthus on (apparently) alternate leaves (with or without the opposite or subopposite but very early-caducous minute second leaf); leaves are also often distinctively distichous and asymmetrical. Leaves of Procris (q.v.) are superficially very similar. Inflorescence-architecture is extremely variable, ranging from lax cymes to discoid, lobed or subglobose dense heads of flowers on a receptacle and surrounded by an involucre of partly fused bracts. Species delimitation is difficult.

Lecanthus Wedd. (Meniscogyne Gagnep.) Fig. 2d, e (?3 species). Revised by Chen et al. (2003) in the Flora of China.
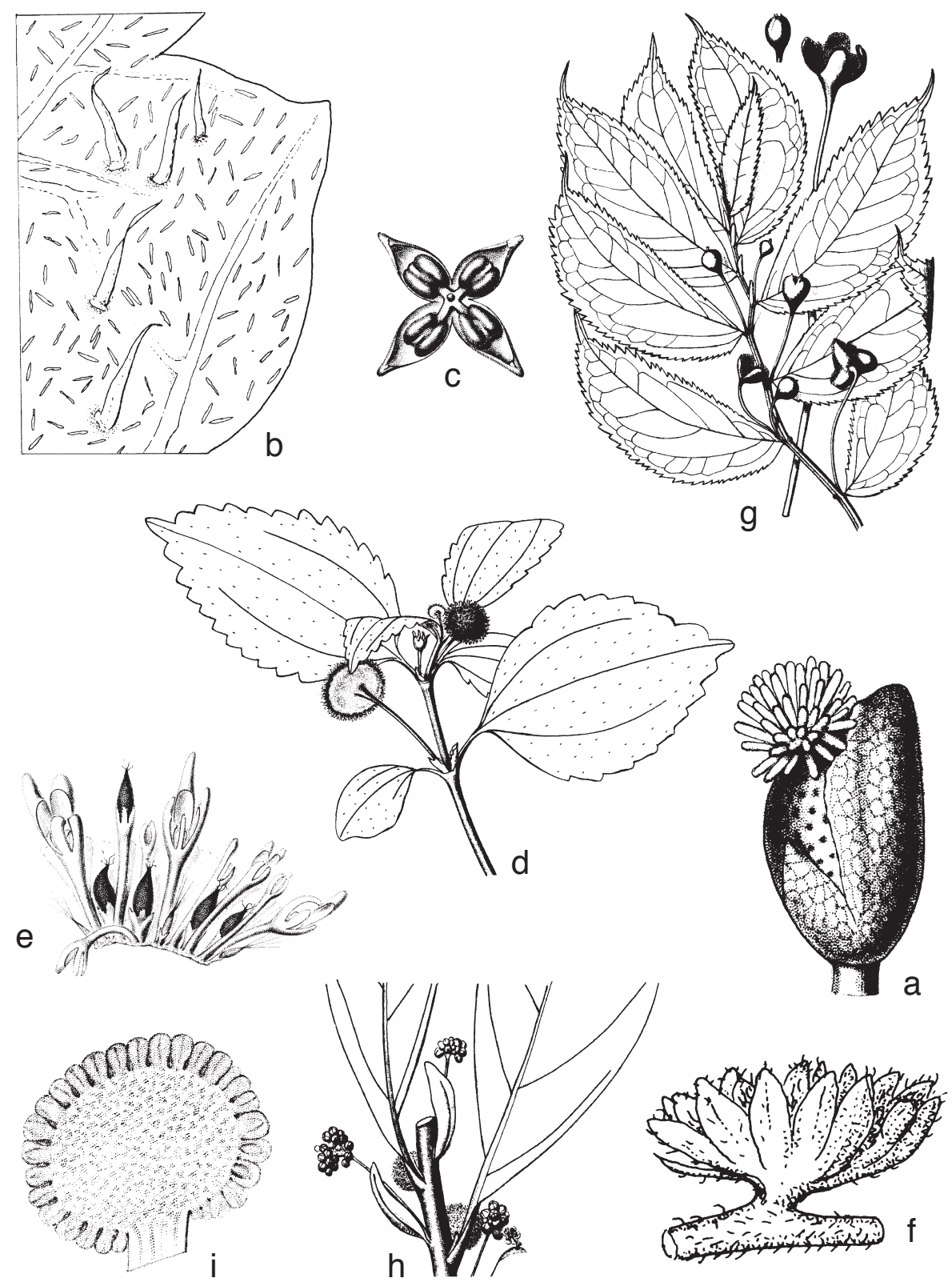

g
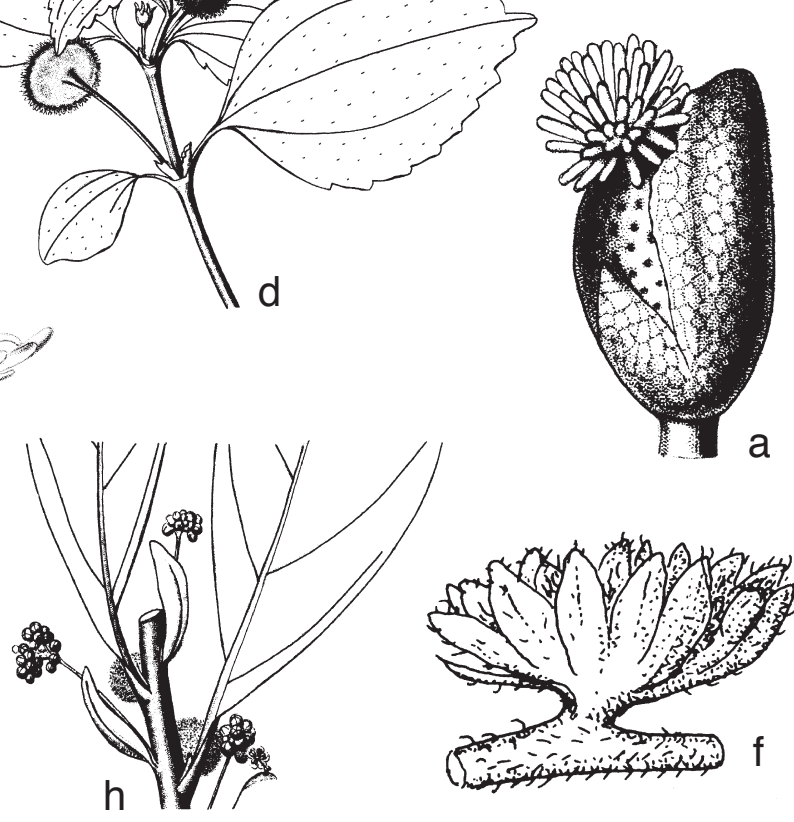

Fig. 2 Tribe Elatostemeae. - a-c. Pilea: a. Pistillate flower; $b$. leaf underside with cystoliths and hairs; c. staminate flower. - d, e. Lecanthus: d. Flowering stem with discoid pistillate receptacles; e. portion of pistillate receptacle. — f, g. Elatostema: f. Pistillate inflorescence showing involucre; g. habit with lobeddiscoid staminate inflorescences and detail of one staminate inflorescence. - h, i. Procris: h. Stem with minute subopposite second leaf, sessile pistillate and pedunculate staminate inflorescences; i. subglobose pistillate inflorescence (a, c-e, g-i: Weddell (1856); b: Friis (1989b, reused with permission from Kew Bull.); f: Friis (1989a), b and $f$ drawn by V. Friis). 
This genus resembles Pilea (q.v.) vegetatively, distinguished by pedunculate cup-like to discoid involucrate receptaculate inflorescences.

Petelotiella Gagnep. (?1 species in Indochina, P. tonkinensis Gagnep.). Closely resembles Elatostema, distinguishable by 3 -merous staminate flowers.

Pilea L. Fig. $2 a-c$ ( $>50$ species in the region). Distinguished from all other genera in the tribe except Lecanthus by its opposite leaves. (Lecanthus differs in capitate-involucrate inflorescences). Pilea is distinguishable from all other genera in Urticaceae by its combination of linear cystoliths, opposite leaves and non-capitate inflorescences.

Procris Juss. Fig. 2h, i (c. 10 species, almost all in the region). Monographed by Schroeter \& Winkler (1936). It often has succulent stems, but is easily confused with Elatostema, differing only in its pistillate inflorescences always being subglobose but without an involucre. Most species have a minute opposite or subopposite very early caducous second leaf.

Tribe 3. Boehmerieae (c. 18 genera, 13 in the region) Fig. 3-5

This is the largest tribe and the hardest to identify to genus, because the delimitation is difficult between certain genera, often dependent on characters of the tiny pistillate flowers. Additionally, certain pairs of taxa in clearly distinct genera are almost identical vegetatively and impossible to distinguish without flowers. Characters strongly indicating this tribe (where present) are discolorous leaves or dense subspherical stalked or sessile 'heads' of flowers.
Archiboehmeria C.J.Chen (1 species in Indochina, A. atrata (Gagnep.) C.J.Chen). Revised by Chen et al. (2003). It is a small alternate-leaved herb easily misidentified as a rather depauperate Boehmeria and distinguishable only by the short-ligulate rather than filiform stigma.

Astrothalamus C.B.Rob. (monotypic: A. reticulatus C.B.Rob.). It is a shrub or small tree with inflorescences unlike any other genus. Pistillate flowers are borne on the upper surface of broad flattened lobed recurved 'sponge-like' receptacles, several of which terminate a short peduncle. Staminate inflorescences are also distinctive with flowers arranged on the flattened slightly elongated apex of each branch but these flattened apices are narrow and less easy to interpret (although plants are monoecious with the more distinctive pistillate inflorescences usually present). Its discolorous leaves are almost identical to Boehmeria nivea Gaudich. and to some species of Maoutia (both can only be distinguished easily when inflorescences are present).

Boehmeria Jacq. Fig. 3, 4f-h (> 20 species in the region). New World species revised by Wilmot-Dear \& Friis (1996); Old World revision (Wilmot-Dear \& Friis in prep.). This genus of herbs, shrubs and trees is widely varying in leaf morphology and inflorescence architecture and is therefore closely similar vegetatively to various other genera $(B$. nivea Gaudich. is vegetatively identical to Maoutia puya Wedd.). It is easily distinguished from most other genera in the tribe by its filiform rather than capitate stigma, but frequently confused with Pouzolzia, Pipturus and Cypholophus, which also have a filiform stigma. Pouzolzia is distinguished only by its shiny rather than dull achene and (usually) caducous stigma; the major differences between the two are in the anatomy of the fruiting perianth and outer layers of the achene. In Pouzolzia fruit ornamentation (ribs or wings) where present is formed

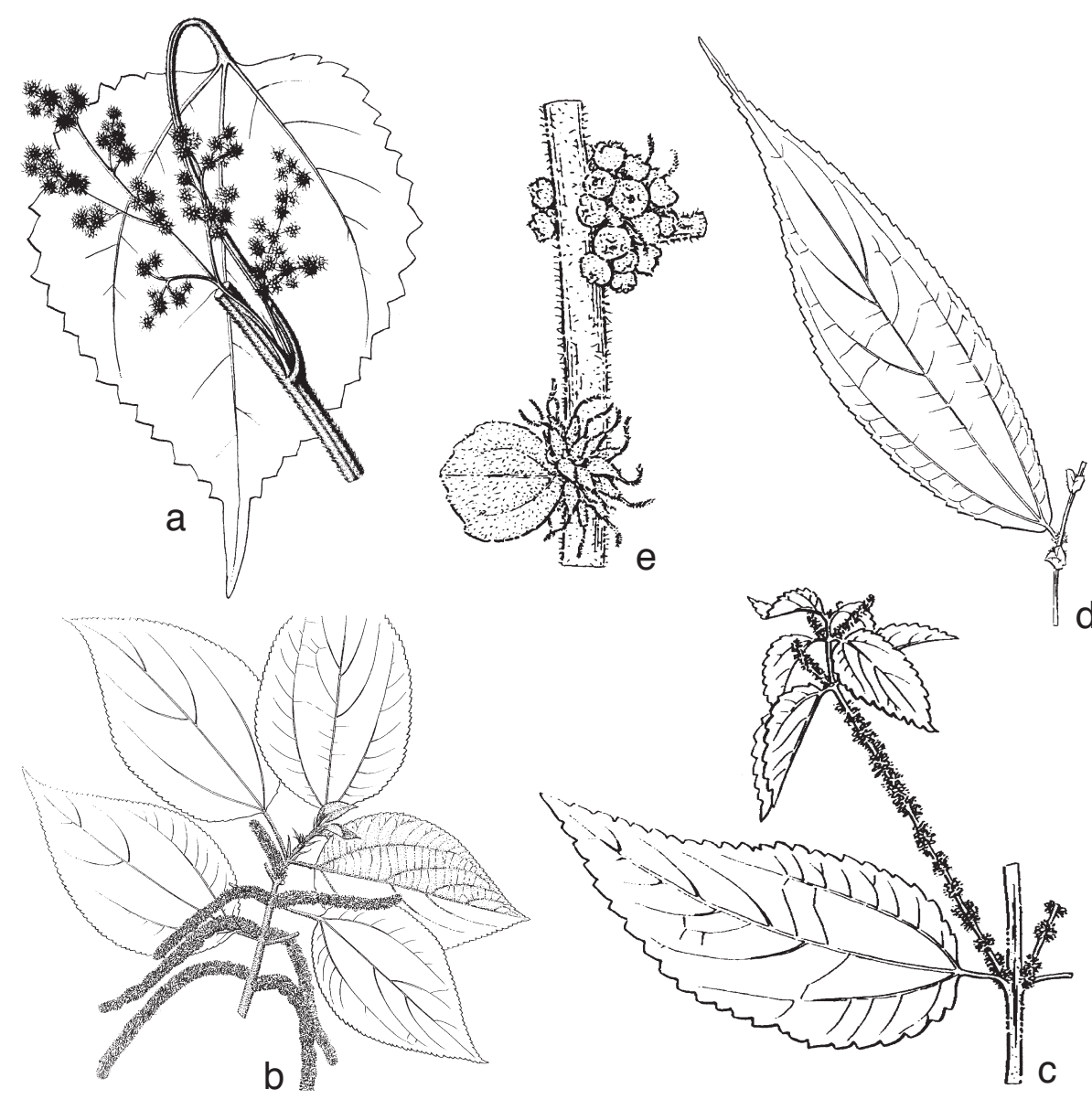

Fig. 3 Tribe Boehmerieae, variation in inflorescence architecture in Boehmeria. a. Paniculate inflorescences; b. subglobose flower-clusters contiguous along spike-like leafless axes; c. spike-like axes with apical leaf-tuft; d, e. subopposite and alternate dimorphic leaf-pairs with axillary subglobose staminate and pistillate flower-clusters (a: Weddell (1856); b-e: Wilmot-Dear \& Friis (1996, reused with permission from Opera Bot.), drawn by Eleanor Catherine). 

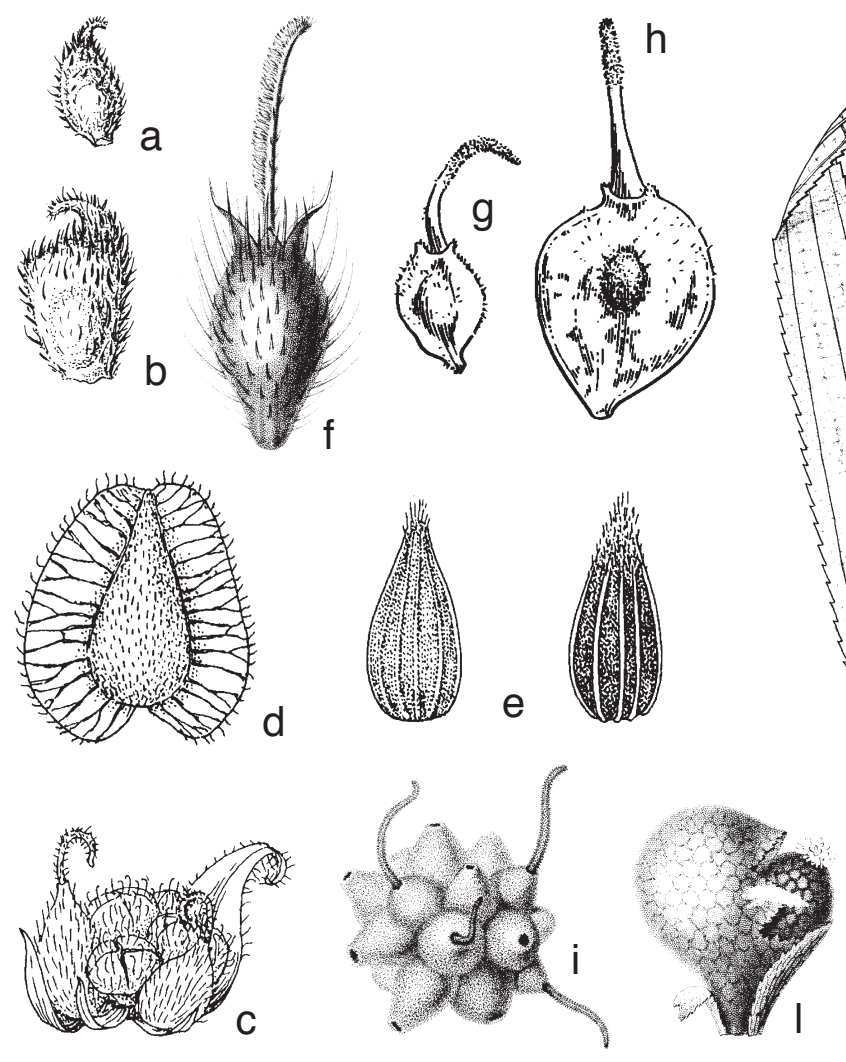

by perianth tissue; in Boehmeria fruit ornamentation is derived from the pericarp (outer layers of the achene). For differences from Pipturus see that genus. Cypholophus (q.v.) differs mainly in the minute tightly curled stigma and fleshy fruiting perianth.

Chamabainia Wight (1 species: C. cuspidata Wight). Revised by Chen et al. (2003). It is an opposite-leaved herb indistinguishable from Boehmeria except by its capitate stigma.

Cypholophus Wedd. Fig. 4a, b (c. 30 species). Close to Boehmeria and often misidentified, distinguished from it by its minute (< $1 \mathrm{~mm}$ long) tightly-curved stigma, its slightly asymmetrically ovoid or obovoid pistillate perianth not constricted into a beak at the apex and its distinctly asymmetrical slightly fleshy fruiting perianth (in dried material only the broad wrinkled apical part of the perianth indicates this). Differences between the two genera are discussed by Wilmot-Dear \& Friis (1998). Leaves are opposite with a dense sessile flower cluster in each axil.

Debregeasia Gaudich. Fig. 5a-d (6 or 7 species). Revised by Wilmot-Dear (1988) and Chen et al. (2003, Chinese taxa). It is a shrub or tree with alternate leaves distinctive in repeatedly-dichotomous inflorescences terminated by many-flowered subglobose clusters; pistillate flowers are arranged on a receptacle; its stigma is penicillate or capitatepenicillate, sometimes almost ligulate; flowers have a tubular often fleshy perianth completely enveloping the achene and often tightly adnate to it (one species confusingly also has 3 bracteoles so large as to envelope the fruit, mimicking free perianth lobes). Boehmeria sometimes has similar inflorescence architecture, but is distinguished by its filiform stigma, no receptacle and its perianth is not distinctly fleshy. Leucosyke and Maoutia (stigma capitate) are more easily confused with it, but distinguished by pistillate perianth being non-fleshy and shorter than achene; Maoutia also differs in smaller looser clusters without a distinct receptacle. Oreocnide (q.v.) has similar inflorescence architecture but looser clusters where each pistillate flower is partially enveloped by its own separate fleshy receptacle.
Leucosyke Zoll. \& Moritzi. Fig. 5e-g and Maoutia Wedd. (Gibbsia Rendle) Fig. 5h (15-20 species). Partially revised but not published by $\mathrm{H}$. den Bakker. It is a shrub or small tree with alternate leaves and a capitate stigma. Leucosyke is characterised by paired axillary short-pedunculate dense subglobose heads of flowers, the pistillate flowers arranged around a receptacle with thin-textured perianth surrounding only lower part of achene, while Maoutia has dichotomouslybranched inflorescences with few-flowered clusters without a distinct receptacle and an extremely inconspicuous pistillate perianth. These taxa are often confused with Debregeasia (q.v.).

Neodistemon Babu \& A.N.Henry (1 species, N. indicum Babu \& Henry). Its systematic position within the family is uncertain. It is a small slender alternate-leaved herb with fewflowered clusters along leafless axes very closely resembling Boehmeria and Pouzolzia, distinguished mainly by 2-merous rather than 3-5-merous staminate flowers.

Nothocnide Blume (c. 4 species) Revised by Chew (1969a). Very close to Pipturus (q.v.), but distinguishable by climbing rather than shrubby erect habit. It has alternate leaves; flower clusters are along unbranched axes.

Oreocnide Miq. Fig. 5i-k (c. 12 species, ?8 in the region). Chinese taxa revised by Chen et al. (2003). It is a shrub with somewhat similar inflorescence architecture to Debregeasia but looser clusters with lobed, thinner-textured pistillate perianth and each flower is partly or almost completely enveloped by its own separate conspicuous fleshy discoid or cup-like receptacle. Dried material, where the fleshy receptacle is no longer so clearly seen, can be confused with Maoutia, which has similar inflorescence architecture and loose flower clusters.

Pipturus Wedd. Fig. 4i (c. 20 species). Partial revision by K. Eichhorn (L), but not yet published. It is a shrub or small tree with flower-clusters sessile or along axes extremely similar in leaves and inflorescences to Nothocnide (q.v.). It is also often confused with Boehmeria or Pouzolzia, which are both often similar vegetatively and in flower. It is distinguishable 

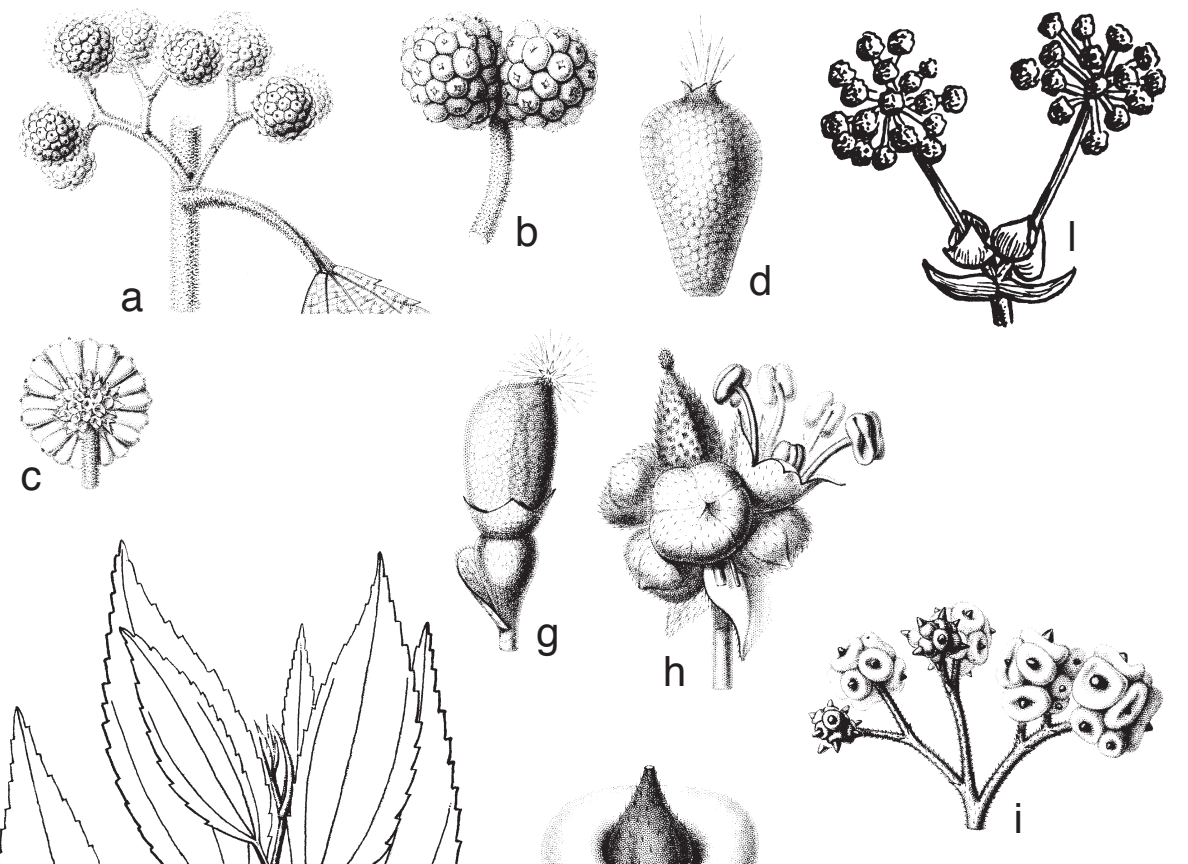

Fig. 5 Tribe Boehmerieae and Poikilospermum, genera with capitate-penicillate or peltate stigma. a-d. Debregeasia, pistillate inflorescences: a. Pair of axillary dichotomous inflorescence-axes; b. peduncle with pair of fruiting clusters; c. cluster with fruits removed to show receptacle; $d$. flowering perianth and capitate-penicillate stigma. - e-g. Leucosyke: e. Stem with paired pedunculate subglobose inflorescences; f. pistillate inflorescence, longitudinal section to show flowers arranged on receptacle; g. fruit with capitate-penicillate stigma, perianth surrounding lower part of achene. - h. Maoutia bisexual fruiting cluster with 5-merous staminate flowers. - i-k. Oreocnide: i. Dichotomous axes with subglobose clusters, each fruit surrounded by pale fleshy receptacle; j. pistillate flower and basal receptacle, longitudinal section; $k$. fruit and receptacle. - I. Poikilospermum, inflorescence showing conspicuous bracts (a-k: Weddell (1856); I: Chew (1963, reused with permission from Gard. e

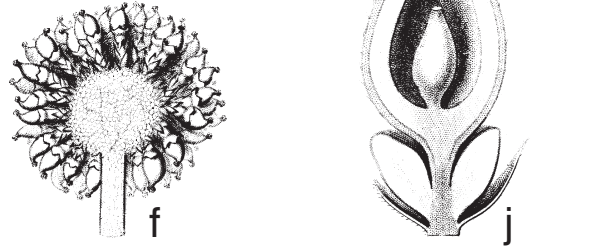
Bull. Singapore)).
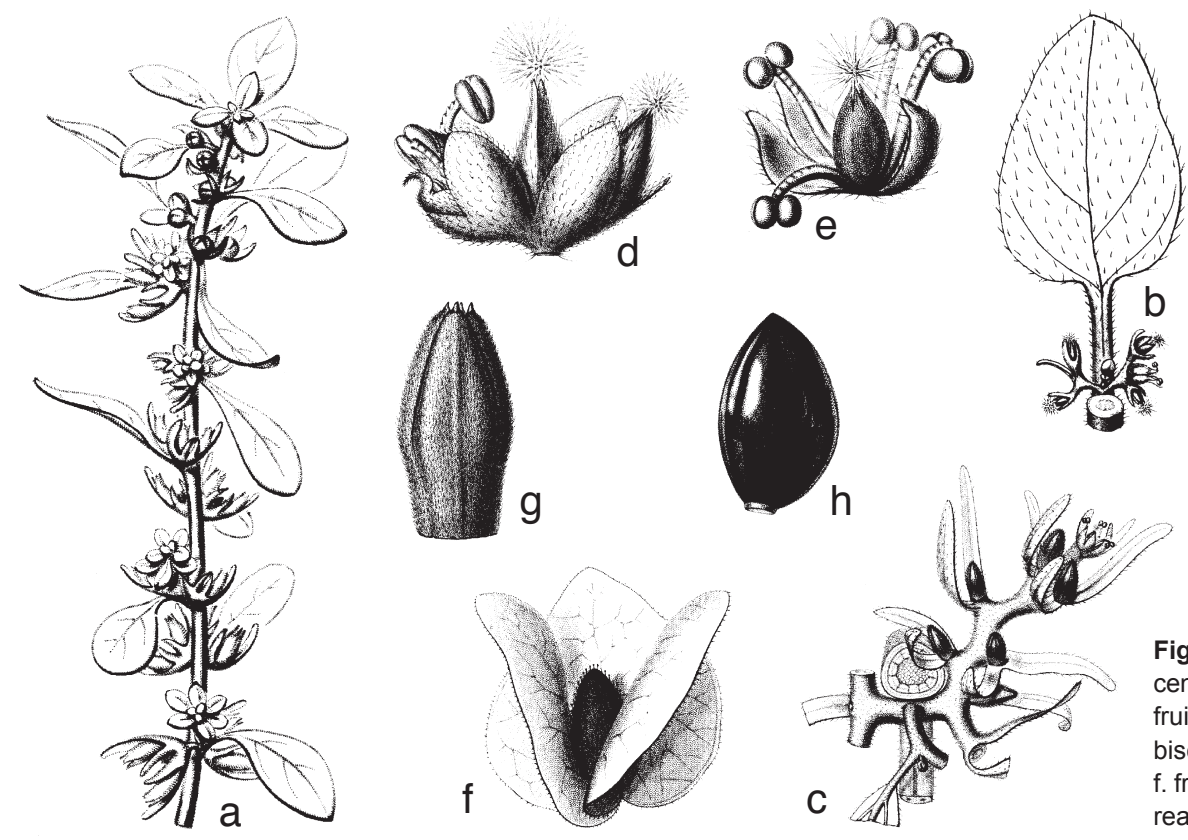

Fig. 6 Parietaria. a. Habit; b. leaf with axillary inflorescence; $c$. part of inflorescence showing bracts subtending fruits and a terminal staminate flower; $d$. cluster with one bisexual and two pistillate flowers; e. bisexual flower; f. fruit subtended by leaf-like bracts; $g$. fruit with perianth ready to dehisce; h. achene (all: Weddell (1856)). 

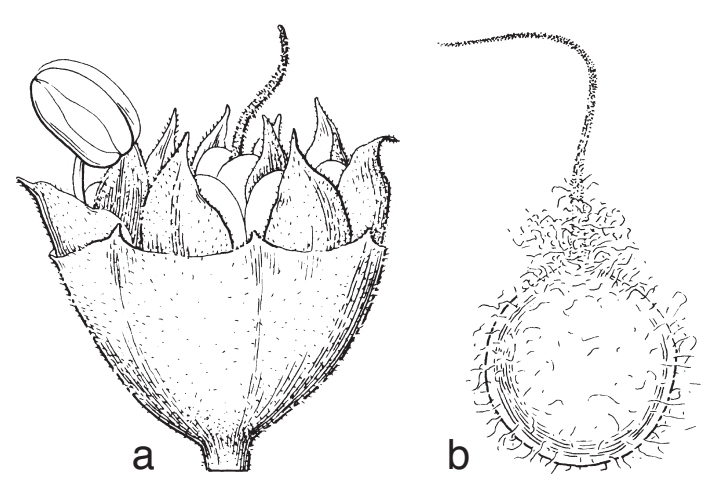

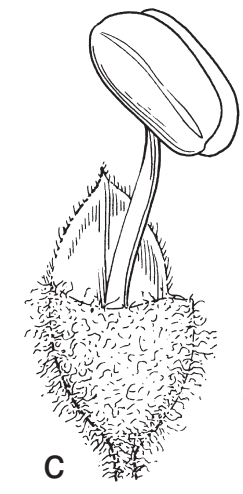

Fig. 7 Tribe Forsskaoleeae, Droguetia. a. Bisexual inflorescence with one stigma, many anthers and apices of many staminate perianths visible within involucre; b. pistillate flower; c. staminate flower (all: Friis \& Wilmot-Dear (1988, reused with permission from Kew Bull.), drawn by Eleanor Catherine). from these two genera only by the pistillate perianth, which is succulent at maturity with a dark 'hole' at the apex after the early-caducous stigma has fallen; this dark hole is clearly visible with a hand-lens and usually also to the naked eye. Immature fruits or those with dense indumentum obscuring the apex are easily misidentified. Fruits in Pipturus are also never markedly laterally compressed, nor winged or ribbed.

Pouzolzia Gaudich. (Gonostegia Turcz.; Hyrtanandra Miq.; Memorialis (Benn. \& R.Br.) F. Hamilton). Fig. 4c-e (36 species, 8 in the region). The Old World species were revised by WilmotDear \& Friis (2006). It is a herb, shrub or small tree frequently confused with Pipturus or Boehmeria (q.v.) with almost as wide a range of habit and leaf morphology as in Boehmeria. Its fruit form is even more variable and both winged and unwinged fruits can occur on one plant (Fig. 4d, e).

Sarcochlamys Gaudich. Fig. 4j-I (monotypic, S. pulcherrima Gaudich., Indochina). It is a shrub or small tree with inflorescences unlike any other genus, consisting of a slightly flattened axis with short lateral branches throughout its length, the whole length completely obscured on one side by a continuous mass of flowers in small but contiguous clusters. Its long linear-elliptic discolorous leaves are almost indistinguishable from Debregeasia longifolia Wedd.

Tribe 4. Parietareae (5 genera, 1 in the region)

Parietaria L. Fig. 6 (?1 species in the region, P. debilis G. Forst.). This genus of small alternate-leaved herbs is easily distinguishable from all other genera in the region by its conspicuously contrasting green, light brown and black inflorescence parts as described in the key. Infrageneric entities are morphologically very plastic, giving rise to the problem of unharmonised regional treatments of overlapping taxa. Non-flowering material is often confused with the widespread species Pouzolzia zeylanica L. Material with particularly minute leaves can also be confused with certain minute-leaved species of Pilea, because the alternate versus opposite leaf arrangement is difficult to see.
Tribe 5. Forsskaoleeae (4 genera, 1 in the region)

Droguetia Gaudich. Fig. 7 (1 species in the region, D. iners (Forssk.) Schweinf.). Tribe revised by Friis \& Wilmot-Dear (1988). This species resembles a small herbaceous Boehmeria in habit and is frequently misidentified, because the diagnostic floral characters are minute and difficult to observe.

\section{REFERENCES}

Chen Jiarui, Lin Qi, Friis I, Wilmot-Dear CM, Monro AK. 2003. Urticaceae. In: Wu Z, Raven PH (eds), Flora of China 5 (Ulmaceae through Basellaceae): 76-189. Science Press, Beijing.

Chew WL. 1963. A revision of the genus Poikilospermum. Gardens' Bulletin Singapore 20: 2-103.

Chew WL. 1965. Laportea and allied genera. Gardens' Bulletin Singapore 21: 195-208.

Chew WL. 1969a. Nothocnide in Malesia. Gardens'Bulletin Singapore 24: 361 373.

Chew WL. 1969b. A monograph of Laportea. Gardens' Bulletin Singapore 25: $11-177$.

Friis I. 1981. A synopsis of Girardinia. Kew Bulletin 36: 143-157.

Friis I. 1989a. Urticaceae. In: Polhill RM (ed), Flora of Tropical East Africa: 1-64. Balkema, Rotterdam, Brookfield.

Friis I. 1989b. A revision of the genus Pilea Lindl. in Africa. Kew Bulletin 44: 557-600.

Friis I, Wilmot-Dear CM. 1988. A revision of the tribe Forsskaoleeae (Urticaceae). Nordic Journal of Botany 8: 25-59.

Schroeter H, Winkler A. 1936. Monographie der Gattung Procris. Feddes Repertorium 45: 179-192, 257-300.

Weddell HA. 1856-1857. Monographie de la famille des Urticacées. Archives du Museum d'Histoire Naturelle 9: 1-592.

Wilmot-Dear CM. 1988. An account of the genus Debregeasia (UrticaceaeBoehmeria). Kew Bulletin 43: 673-692.

Wilmot-Dear CM, Friis I. 1996. The New World species of Boehmeria and Pouzolzia (Urticaceae, tribus Boehmerieae). Opera Botanica a Societate Botanica Lundens 129: 1-103.

Wilmot-Dear CM, Friis I. 1998. Cypholophus decipiens (Urticaceae). - Taxonomy and range of a species often misplaced in Boehmeria. Kew Bulletin 53: 919-927.

Wilmot-Dear CM, Friis I. 2006. The Old World species of Pouzolzia (Urticaceae). Nordic Journal of Botany 24: 1-115. 